\title{
A INSTRUMENTALIZAÇÃO DA SUBJETIVIDADE NO TRABALHO PELO CAPITAL*
}

\author{
Ricardo Colturato Festi ${ }^{1}$
}

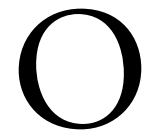

$s$ estudos recentes de Danièle Linhart problematizam e analisam os discursos disseminados pelos altos quadros do capital sobre as atuais condiçóes de trabalho. Esses discursos pintam um cenário positivo da "moderna" forma de gestão empresarial e demonstram uma preocupação com a qualidade e a segurança dos locais de trabalho e do bem-estar do trabalhador, mas tal imagem se contrasta com o aumento, sem precedentes nas últimas décadas, do sentimento de mal-estar e de sofrimento daqueles que vivem do trabalho. A estudiosa trata desse tema em seu mais recente livro - que pode ser traduzido como A comédia humana do trabalho: da desumanização taylorista à hiper-humanização gerencial — e defende a tese de que o drama do trabalho contemporâneo não se origina apenas da desumanização proporcionada pelo capital e seu maquinário, mas também pelo fato do atual modelo de gestão mobilizar a seu favor os aspectos mais profundamente humanos da subjetividade dos trabalhadores.

Danièle Linhart é francesa, socióloga do trabalho, diretora de pesquisa emérita do Laboratoire Travail, Genre et Mobilités do Centre National de la Recherche Scientifique (CNRS) e docente da Université Paris Ouest Nanterre La Défense. Publicou, entre outros livros, Travailler sans les autres? (Seuil, 2009), La modernisation des entreprises (La Découverte, 2010) e, em português, A Desmedida do capital (Boitempo, 2007). No mundo acadêmico brasileiro, seus estudos têm se tornado conhecidos por meio de um intercâmbio de ideias e projetos de pesquisa estabelecido com professores, pesquisadores e estudantes de nosso país, além da publicação de artigos e capítulos em revistas e livros.

Em trabalhos recentes, como é o caso de seu artigo publicado no volume III de Riqueza e Miséria do Trabalho no Brasil (2014), organizado pelo professor Ricardo Antunes, a autora analisa as novas formas de ser do trabalho e seus impactos sobre os trabalhadores através do conceito "precariedade subjetiva". Trata-se de um fenômeno de precarização que atinge a esfera subjetiva do assalariado através da imposição de ideais e metas de produção e de serviços impossíveis de serem

\footnotetext{
*Resenha do livro de Linhart, Danièle. La comédie humaine du travail: de la déshumanisation taylorienne à la sur-humanisation managériale. Toulouse, France: Éditions Érès, 2015. 158 p. ${ }^{1}$ Universidade Estadual de Campinas, Colégio Técnico de Limeira (COTIL) - Campinas (SP), Brasil. E-mail: ricardofesti@gmail.com DOI: 10.1590/ES0101-73302016161454
} 
atingidos, num ambiente de trabalho cada vez mais individualizado e ausente de uma identidade de classe entre os trabalhadores. Já em A comédia humana do trabalho, Linhart envereda no difícil terreno da crítica às ideologias triunfalistas do capitalismo contemporâneo.

A autora analisa, nele, os manuais de administração e recorre a seus cadernos de anotaçóes de campo e a experiência de décadas de observação e participação em eventos voltados aos quadros gerenciais de grandes empresas francesas. Ela propõe uma síntese desse novo modelo gerencial, sob três eixos fundamentais:

1. os managers não podem se contentar em definir as práticas, os dispositivos e as estratégias das empresas em função das qualidades e especificidades de seus "parceiros" (um dos eufemismos da linguagem gerencial para operários), mas devem moldá-los para os seus objetivos através do cultivo de qualidades individuais julgadas adequadas, ao mesmo tempo em que descartam a experiência profissional destes, considerada um obstáculo à gestão;

2. essas "qualidades adequadas" são as que ressaltam as características mais humanas, tais como a felicidade, a necessidade de se descobrir, a fidelidade, a confiança nos outros, o espírito de sacrifício, dentre outras; e

3. cabe ao gerente e ao departamento de recursos humanos a responsabilidade de ajudar os seus "associados" a encontrar a felicidade e o sentido em seus trabalhos. Dessa forma, ao mesmo tempo em que as empresas passam a utilizar a subjetividade do trabalhador para intensificar o trabalho, criam uma imagem positiva delas mesmas.

Apesar de um discurso voltado ao "moderno" e ao novo, Linhart demonstra que as formas contemporâneas de gestão empresarial mantêm os mesmos princípios e muitos dos aspectos que impulsionavam o modelo taylorista-fordista. Além do mais, o projeto pretensamente científico da "organização racional do trabalho", presente nos dois modelos, não deixa de ser um discurso ideológico (no sentido de falseamento da realidade), com o objetivo de construir uma relação não conflitiva e despolitizada entre capital e trabalho.

No início do capitalismo monopolista, Henry Ford percebeu que precisava estabelecer um novo modo de vida entre os operários para garantir uma reprodução estável da sua força de trabalho, capaz de aguentar o ritmo acelerado, monótono, repetitivo e fatigante da fábrica. $\mathrm{O}$ operário ideal seria um homem jovem, casado, preocupado com as suas economias domésticas, com a higiene da sua casa e a sua alimentação, seguindo uma vida regrada, sem badalaçóes e excesso de álcool. Para cumprir esse objetivo, criou em suas fábricas departamentos específicos e jornais para difundir esses ideais. O modelo contemporâneo tem o mesmo propósito de controlar a vida dos trabalhadores nas esferas não fabris 
em vista de uma maior produtividade e uma relação não conflitiva. Contudo, diferente do modelo antigo, o atual teve maior eficácia nesse objetivo, ao conseguir atingir o âmbito subjetivo dos trabalhadores e atacar as suas formas de solidariedade de classe.

Portanto, a ruptura do novo modelo de gestão com o taylorismo-fordismo está em sua forma e não em seus princípios, sendo que os maiores impactos dessas mudanças recaíram sobre os trabalhadores. A produção fordista se hegemonizou num período de contínuo crescimento econômico, de aumento da produtividade e das altas taxas de lucro. $\mathrm{O}$ forte poder de barganha dos sindicatos os permitiram conquistar salários fabris relativamente altos, ao longo de um período de grandes convulsóes operárias. Já o novo modelo de gestão se consolidou no período de crise estrutural do capital e de relativa baixa das taxas de lucro e na ascensão do neoliberalismo. A disseminação da tese de que a atual precariedade estimularia os indivíduos, já que a competição seria uma condição sine qua non do trabalho (e de sua criatividade), ocorreu concomitante ao enfraquecimento dos sindicatos e ao desaparecimento da solidariedade de classe.

Nesse novo cenário, o desprestígio à experiência profissional de cada trabalhador é acentuado pela flexibilização da produçáo e pela permanente atualização do maquinário. A nova "ciência gerencial" assumiu as tarefas que antes eram parte do saber, da experiência e da qualificação dos trabalhadores, produzindo o que a autora chamou de "desprofissionalização", ou seja, a perda do saber fazer. Os aspectos mais importantes para os managers não são os diplomas, as especializaçôes e as qualificaçóes, mas a personalidade, as capacidades cognitivas e emocionais dos trabalhadores.

[...] a desprofissionalização visaria a mobilizar os aspectos humanos que seriam mais fáceis de controlar, de colonizar. $\mathrm{O}$ importante seria, do ponto de vista gerencial, de náo depender dos assalariados, que devem ser controlados; aposta-se no fato de que eles são mais fáceis de se sujeitarem, ao geri-los mais como humanos que profissionais. O objetivo é, portanto, reduzir a capacidade de protesto e de oposição, mas também a incerteza e a imprevisibilidade que carrega cada indivíduo. (p. 143)

Linhart compreende que essa nova forma de gestão foi uma reação ao último grande ascenso operário e popular ocorrido no mundo ocidental entre os anos de 1960 e 1980. Seus mecanismos de gestão objetivaram desarticular a força da organização coletiva dos trabalhadores através do processo de individualização, caracterizado pela flexibilizaçáo dos horários de trabalho, pelo aumento dos prêmios individuais e pela implementação da lógica de prestação de serviços entre os próprios trabalhadores. Portanto, as experiências coletivas dáo lugar às experiências individuais e, agora, os trabalhadores se encontram sozinhos em seus locais de trabalho, responsáveis pelos seus sucessos e fracassos na profissão. 
Com a desprofissionalização e a individualização nas novas relações de trabalho, os managers puderam implementar diferentes formas de diálogos entre eles e os trabalhadores, como sáo os casos dos círculos de qualidade, sem que esses espaços apresentassem um risco à ordem instaurada no interior das empresas. Dessa forma, os trabalhadores passaram, nos discursos dos managers, a serem considerados a "peça" mais importante das empresas. Suas opiniōes e inteligência são mobilizadas para melhorar a produtividade para, a partir disso, como contrapartida, aumentar o engajamento dos trabalhadores no trabalho, construindo um consenso e moldando a identidade dos assalariados em busca de sua adesão à filosofia das empresas.

O livro é uma contribuição ao debate acerca das formas de configuraçáo do universo subjetivo da sociedade que se instaurou nas últimas décadas. No interior da sociologia francesa, ele segue uma direção parecida às teses defendidas em livros como $O$ novo espirito do capitalismo (1999) de Luc Boltanski e Ève Chilapello. Ao contrário de uma ética ascética do trabalho, como formulou Max Weber em sua obra clássica, que tinha como exigência um afastamento do gozo dos bens acumulados, a nova subjetividade valoriza o gozo supérfluo, o consumismo e a individualização extrema sob relaçóes contingenciais e reificadas. A constituição dessa subjetividade tem sérias implicaçôes políticas sobre a consciência de classe dos trabalhadores. Essa problemática, embora não seja abordada diretamente nessa obra de Linhart, é suscitada pela leitura do livro, o qual nos aporta para novas reflexóes.

Resta-nos aguardar pela edição brasileira de La comédie humain du travail.

Recebido em 22 de março de 2016.

Aprovado em 31 de maio de 2016. 